\title{
Effect of the Interaction Between Monsoon Currents and Waves on the Morphological Processes along the Mekong River Delta Coast
}

\author{
Thanh LETRUNG ${ }^{1}$, Trieu Anh NGOC ${ }^{1,2}$ and Kazuaki HIRAMATSU* \\ ${ }^{1}$ Thuyloi University - South Campus \\ (No. 2 Truong Sa, Binh Thanh, Ho Chi Minh, Vietnam) \\ ${ }^{2}$ Laboratory of Water Environment Engineering, Division of Bioproduction Environmental Sciences, \\ Department of Agro-environmental Sciences, Faculty of Agriculture, Kyushu University \\ (Higashi-ku, Fukuoka 812-8581, Japan)
}

\begin{abstract}
One of the longest rivers in the world, the Mekong River flows through eight estuaries into the East Sea off Vietnam. In recent decades, the complex morphological evolution of the Mekong River Delta coast has affected the livelihoods of local people and the development of Vietnam's major economic area in the south. In this study, large-scale numerical models were created to simulate the long-term morphological processes along the Mekong River Delta coast. By using these models, key factors such as river currents, tides, sediment discharge, monsoon currents, waves, and salinity were calculated under various conditions, including seasonal variations of river flow, monsoon surface sea currents, and waves. The results show that the river flow rate determines erosion and deposition in the river. Furthermore, the river current combined with tidal current governs the development of narrow passages and islets. The effect of the interaction between the monsoon current and waves on the morphological processes of the coastline is significant. The monsoon current plays a major role in changing the shoreline, whereas wave action is a secondary factor that intensifies shoreline erosion, which is primarily influenced by sea current.
\end{abstract}

Discipline: Agricultural Engineering

Additional key words: Sediment transport, morphological evolution, Mike 21 Coupled FM

\section{Introduction}

The morphological processes occurring in estuaries are extremely complex (Holeman 1968, Letrung et al. 2013, Teisson 1991). These natural processes such as river flows, tidal currents, wind, and waves change the geomorphology and shape of an estuary (Julien 1998). This morphological evolution contributes both positively and negatively to the environment and the economy. Sedimentation is also of vital concern in the conservation, development, and utilization of soil and water resources (Gottschalk 1977).

The Mekong River originates in the snowy mountains of the Tibetan Plateau and has historically emptied water into the East Sea through nine estuaries. And among these estuaries, the Bassac estuary settled in the 1960s and the Ba Lai estuary has nearly reached settlement in recent years due to long-term sedimentation. The closure of these two estuaries highlights the conditions of severe sedimentation in the Mekong River estuary. These sedimentation problems depend on many factors such as river currents, sediment flux from upstream, waves, salinity, tides, sea currents, and human activities (Nguyen et al. 2000, Wolanski et al. 1996). The complex interactions among these factors have made accurate estimation of the estuarial evolution nearly impossible for the Mekong River estuary in general, and the Tien River estuary in particular. Most previous sedimentation studies in this area were analyzed by using observation data (Shi \& Zhou 2004, SIWRR 2007), samples from borehole cores (Ta 2001), and remote sensing (Tran \& Tran 2008). For economic reasons, no physical modeling has been conducted thus far.

The few relevant studies include numerical models for small-scale areas and short-term simulations ( Vu 2007, $\mathrm{Vu}$ 2010). The model created by Letrung et al. (2013) was restricted to the Dai and Tieu estuaries and did not cover the entire Mekong River estuary; for simplicity, not all factors

*Corresponding author: e-mail hiramatsu@bpes.kyushu-u.ac.jp

Received 24 Dcember 2014; accepted 25 September 2015. 
were considered. For example, the impacts of waves and salinity were not considered in detail, and sediment transport and bed parameters were not determined by measured data. In the study of Ngoc et al. (2013), two large-scale models were established to investigate the impacts of climate change and SLR on sedimentation processes in the Tien River estuary. Ngoc et al. (2013) showed that morphological evolutions would become too complex to estimate in case of rising sea levels. Therefore, a thorough study on the sediment transport and morphological evolution of the Tien River estuary has yet to be conducted.

The present study is followed by Ngoc et al. (2013), and investigates the processes of erosion and deposition of the Tien River estuary in detail. The East Sea model covers the area of the Mekong River estuarine system and part of the East Sea, while the Mekong River estuary model covers the study area. In this study, the important parameters of sediment transport and bed layer thickness were determined using the sediment transport theory. These parameters were calibrated against observed data on water level, current speed, waves, and sediment concentration in the Tien River estuary. Furthermore, through the application of a mud transport model, the sediment transport, erosion, and deposition over a large coastal area were quantified. Based on a full evaluation of the key factors that affect morphological evolution, this paper reveals the tendencies of erosion and accretion.

\section{Geological Setting and Methodology}

\section{Study area}

The Mekong River is the 11th longest river in the world. The main segment of the Mekong River stretches approximately $4800 \mathrm{~km}$ and has a basin area of 795,000 km². The river's average discharge ranks ninth in the world, at $15,000 \mathrm{~m}^{3} / \mathrm{s}$ (Mekong River Commission 2005). In southern Vietnam, the two primary tributaries of the Mekong River are the Tien and Hau rivers. The Hau River flows straight to the East Sea with two estuaries; however, the platform of the Tien River is oscillatory and complicated before the river empties into the East Sea through six estuaries.

Southern Vietnam experiences a typical Asian tropical monsoon climate. The wet season extends from May to November, and the dry season from December to April every year. Southwest (northeast) winds dominate in the wet (dry) season. Moreover, seasonal variation is evident in the discharge of the Mekong River. About $90 \%$ of the annual rainfall occurs in the wet season; runoff greater than $85 \%$ of the total annual runoff occurs during the flood season. The maximum discharge of the Mekong River exceeds $60,000 \mathrm{~m}^{3} / \mathrm{s}$ in the wet season, whereas it only reaches $2,000 \mathrm{~m}^{3} / \mathrm{s}$ in the dry season ( $\left.\mathrm{Vu} 2007\right)$.

In the study area, the directions of waves and wind are similar, and influenced by the Asian monsoon. Southwest waves dominate in the wet season, and northeast waves prevail in the dry season. Along the southern Vietnam continental shelf (Hoang \& Nguyen 2006), the average wave height is $1.6 \mathrm{~m}$ and the wave period about $5 \mathrm{~s}$. Strong waves occur in the dry season with wave heights exceeding $4 \mathrm{~m}$, whereas in the wet season, the wave height is less than $3 \mathrm{~m}$ and the wave period varies from $5 \mathrm{~s}$ to $12 \mathrm{~s}$.

Strong interaction occurs between river and sea currents in the Mekong River estuary. The tide is dominant in the study area, and the water transitions from fresh to saline of the East Sea. The riverbed here generally consists of very fine cohesive sediment in the form of mud. Fine silt from the rivers is deposited in the wet season, and some is entrained in suspension in the dry season. The sediment of the Tien River exhibits strong seasonal variations. During the flood season, the mean sediment concentration is about $0.20-0.25 \mathrm{~kg} / \mathrm{m}^{3}$. In the dry season, however, the value is approximately $0.07-0.1 \mathrm{~kg} / \mathrm{m}^{3}$, which is one-third of that during the flood season. The sediment concentration in the sea is extremely low. Two longshore currents correspond to the two seasons (Davis \& Hayes 1984, Gagliano \& McIntire 1968, Hayes 1979). A weak warm current flows from south to north in the wet season, whereas a strong cold current flows in the opposite direction during the dry season. The tidal range is from $1 \mathrm{~m}$ to $3.5 \mathrm{~m}$. Saline water intrudes $50 \mathrm{~km}$ upstream of the sea during the dry season. The seawater has salinity exceeding 30\% throughout the year (Mikhailov \& Arakelyants 2010, Nguyen 2009).

\section{Morphodynamic model}

The MIKE 21/3 Coupled Model with flexible mesh (FM) (DHI 2007a), created by DHI Computing Services Inc., is a dynamic modeling system applicable to coastal and estuarine environments. The MIKE 21/3 Coupled Model FM used in this research includes dynamic coupling among the Mud Transport (MT), Sand Transport (ST), Hydrodynamic (HD), and Spectral Wave (SW) modules, which means that full feedback of bed-level changes in wave and flow calculations can be included (DHI 2007c). All of the aforementioned modules of MIKE software were licensed by using a dongle hardware key provided by Thuyloi University, South Campus (formerly Water Resources University, Second Base), which was certified by DHI.

\section{Model setup}

In order to investigate the sediment transport in all of the Mekong River estuaries driven by sea currents and the influence of wave action on coastal erosion, two large-scale models were established: the East Sea model and the Mekong River estuary model. The East Sea model is a regional model covering the entire mouth of the Mekong River and extending to the Bachho and Condao hydrological stations, 
where wave data are available. The Mekong River estuary model is a local model that covers the area from Mythuan and Cantho to the nearshore zone (Fig. 1).

(1) The East Sea model

In the East Sea model, the water level series of hydrological stations at the mouth of the Mekong River were used for the upstream boundary conditions, whereas the predicted tidal elevations were used for the downstream boundaries. Both wind speed and wind direction were based on measured data from the Vungtau hydrological station; monthly wave statistics from the Bachho station were used to specify the offshore wave boundary conditions.
The bathymetry data (recorded in 2006) were provided by Thuyloi University, South Campus. The computed water level and wave results of the East Sea model were extracted for the sea boundary conditions of the Mekong River estuary model (Fig. 2).

(2) The Mekong River estuary model

In the Mekong River estuary model, the upstream boundaries were set at the Mythuan and Cantho hydrological stations, where the hourly time series of discharge data are specified. At the downstream boundaries, water level data were obtained from results computed by the East Sea model.

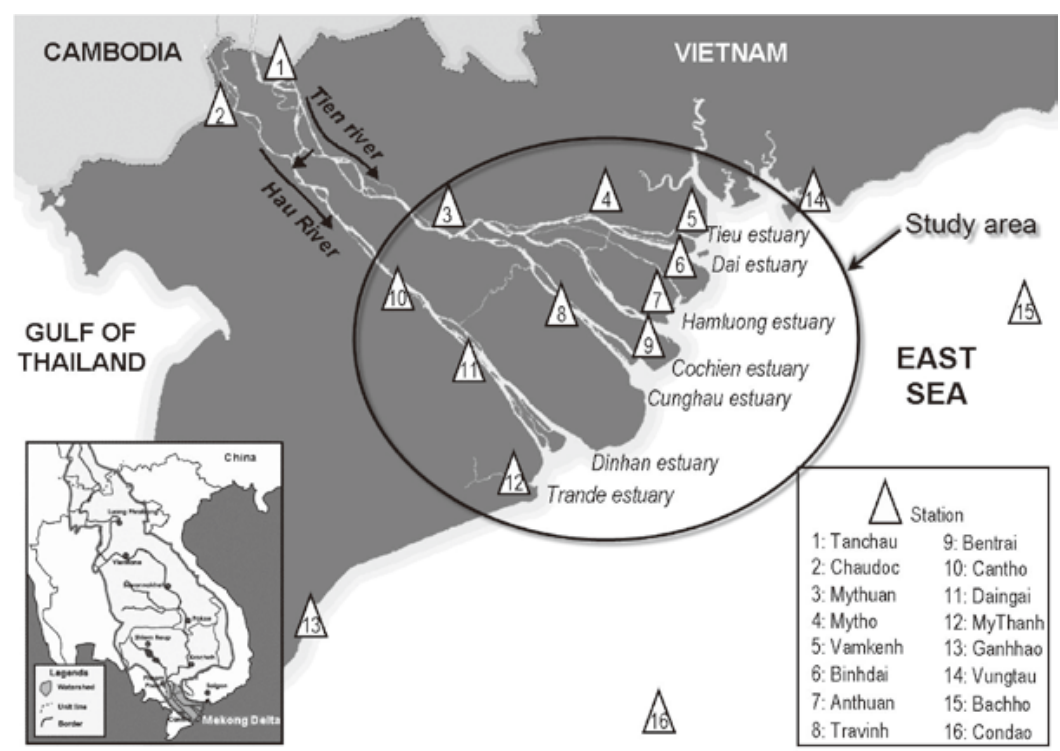

Fig. 1. Location of Lower Mekong River, hydrological stations, and study area

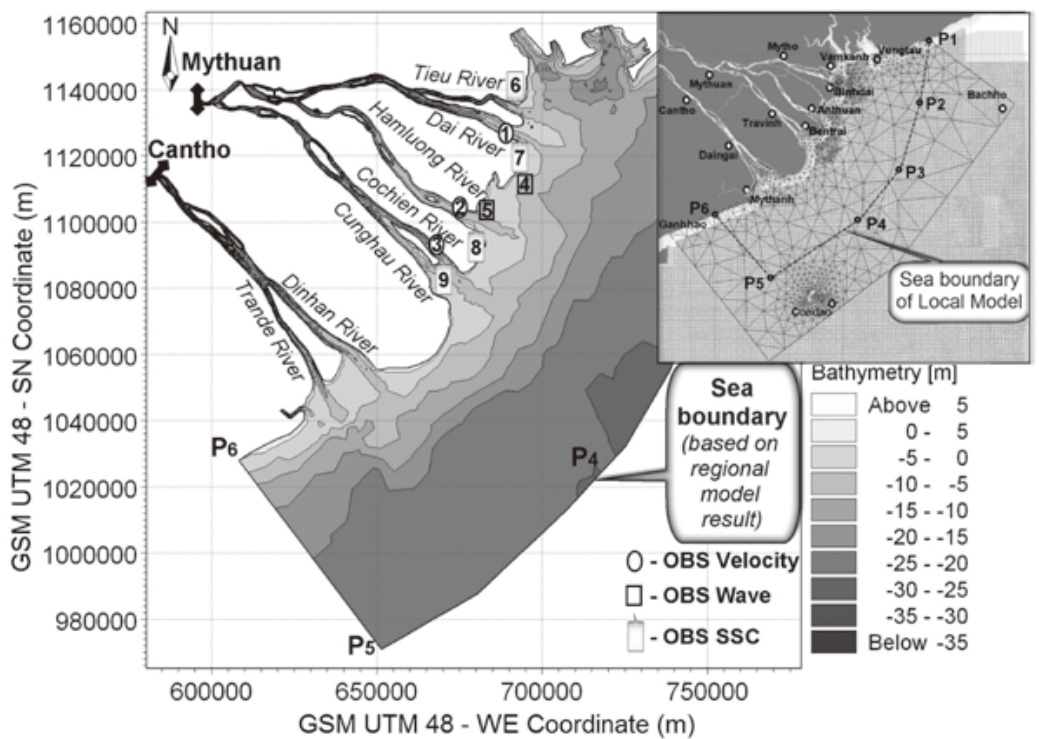

Fig. 2. Unstructured East Sea and Mekong River estuary models 
The wind speed and wind direction were based on measured data from the Vung Tau hydrological station. Herein, the spectral wave results of the East Sea model were chosen for the wave boundary conditions. A mean value of $31 \%$ sea salinity was set as a sea boundary condition. The upstream boundary salinity is negligible at approximately $0 \%$ throughout the year. A value of $26^{\circ} \mathrm{C}$ was chosen for temperature. In addition, sediment concentration mean seasonal values of $0.2 \mathrm{~kg} / \mathrm{m}^{3}$ in the wet season and $0.07 \mathrm{~kg} / \mathrm{m}^{3}$ in the dry season at Mythuan and Cantho were used as upstream boundaries in the East Sea model; $0.0001 \mathrm{~kg} / \mathrm{m}^{3}$ was the downstream boundary.

The hydrodynamic and wave model parameters of the East Sea model and the Mekong River estuary model were determined by Letrung et al. (2013) and Ngoc et al. (2013), with guidance being provided by DHI (DHI 2007a, DHI 2007b, DHI 2007c). Selections of mud transport and bed parameters are described in the following section.

\section{Sediment transport and bed parameters}

In general, the processes of erosion and deposition depend on such parameters as settling velocity $\left(w_{\mathrm{s}}\right)$, critical bed shear stress for deposition $\left(\tau_{\mathrm{crd}}\right)$, erosion coefficient of the bed layer $(E)$, and critical bed shear stress for erosion $\left(\tau_{\text {cre }}\right)$ of bed layers (Krone 1962, Mehta et al. 1989, Teeter 1986). Due to sparse observation data in the Mekong River estuary, the these parameters were determined by model guidance whereby the sediment is assumed to be composed of uniform particles with a representative diameter of less than $63 \mu \mathrm{m}$ in previous studies ( $\mathrm{Vu}$ 2007, Vu 2010). In order to investigate the morphological processes of the Tien River estuary in detail, the present study used newly measured data and the sediment transport theory to analyze and calculate the sediment transport and bed parameters. These parameters were calibrated with observed data from September 2009.

(1) Settling velocity

In the study area, the sediment is composed of nonuniform particles. The suspended sediment ranges from fine silt in the river to sandy mud in the coastal area. In the freshwater region, the particle-size distribution of suspended sediment varies little among site, depth, and tide phase. The median particle size $\left(d_{50}\right)$ varies between $2.5 \mu \mathrm{m}$ and $3.91 \mu \mathrm{m}$, and is classified as very fine silt (Wolanski et al. 1996). In the coastal zone, the median grain size of the sand fraction shows seasonal variation with generally fine sediment appearing in the wet season (Tamura 2010). Flocs of substantial size were noted with a floc $\mathrm{d}_{50}$ of about $40 \mu \mathrm{m}$ detected near the bed (Wolanski et al. 1996). Therefore, the suspended sediment particles of the Mekong River were divided into three main particle sizes. These classifications include clay $(\mathrm{d}=4 \mu \mathrm{m})$, fine silt $(\mathrm{d}=8 \mu \mathrm{m})$, and coarse silt ( $d=32 \mu \mathrm{m})$; the latter is distributed only near the riverbed.
The settling velocity of fine sediment depends on the particle/floc size, temperature, concentration of suspended matter, and content of organic material (Parchure \& Mehta 1985, Rubey 1933). Besides, the flocculation effect also causes the settling velocity to increase with concentration (Shi \& Zhou 2004, SIWRR 2003). Particularly in saline tidal flow, the flocculation effects play a major role (Van Rijn 2007). The influence of salinity on flocculation is important primarily in brackish areas such as estuaries. When the salinity is between 0 PSU (Practical Salinity Unit) and 9 PSU, an increase in flocculation can occur; however, it does not increase further when salinity exceeds 10 PSU (DHI 2007c). In this study, the fall velocity calculated by using the van Rijn formula (Van Rijn 2007) (including flocculation and the effects of suspended sediment concentration) has a larger value than that determined by using Stokes and Rubey equations. In a study of fine sediment transport in the Mekong River estuary, Wolanski et al. (1996) suggested fall velocity values of $0.25 \mathrm{~mm} / \mathrm{s}$ in saltwater and $0.4 \mathrm{~mm} / \mathrm{s}$ in freshwater. Thus, the settling velocity values of 4,8 , and $32 \mu \mathrm{m}$ particles were respectively determined to be $0.02,0.2$, and $1 \mathrm{~mm} / \mathrm{s}$ in the dry season, and $0.04,0.6$, and $1 \mathrm{~mm} / \mathrm{s}$ in the flood season.

(2) Bed parameters

The surface sediment of the riverbed in the Mekong River is composed mainly of clay and silt, and thus has low mud content (Wolanski 1996). According to the Southern Institute of Water Resources Research (SIWRR 2007) and Ta et al. (2001), the bed layers in descending order include a surface sediment layer, sub-aerial delta plain facies, and sub- to intertidal flat sandy silt facies. The thickness of the surface sediment layer is about $0.1-0.3 \mathrm{~m}$, corresponding to $\mathrm{d}_{50}=7-15 \mu \mathrm{m} ; \mathrm{d}_{\text {mean }}=40-50 \mu \mathrm{m}$. Beneath the surface sediment layer is the sub-aerial delta plain facies with a wet bulk density of $1.58 \mathrm{~g} / \mathrm{cm}^{3}$ and a dry density of $0.95-0.99 \mathrm{~g} / \mathrm{cm}^{3}$. The bottom facies is a sub- to intertidal flat sandy silt layer. This facies, about 6-8 $\mathrm{m}$ thick, consists of laminated dark gray sandy silt and fine sand; the grain size of sediments in the estuary is coarser than that in the riverbed. The bulk density of this layer is about $1.85-1.95 \mathrm{~g} / \mathrm{cm}^{3}$, and its dry density range is $1.45-1.53 \mathrm{~g} / \mathrm{cm}^{3}$.

In the morphodynamic model, the erosion formula is based on that proposed by Mehta et al. (1989). Bed layer erosion depends on the critical bed shear stress for erosion, which has been discussed in several theoretical and experimental studies, such as Thorn (1981), van Rijn (2007), Dou (2006), Houwing et al., Houwing (2000), and Hong et al. (2007). Based on the characteristics of the three soft bed layers described above, the values of Dou (2000) and Houwing (2000) were applied for the first and second bed layers. The parameters of the third bed layer were calculated according to the formula of Hong et al.(2007). Table 1 lists the bed parameters finally chosen based on 
trial and error.

\section{Calibration of the Mekong River estuary model}

The hydrodynamic model, wave model, and mud transport of the Tien River estuary were first calibrated by using the observation data on water level, velocity, wave, and sediment concentration recorded in September 2009.

(1) Flow

The computed water level showed very little deviation $(<5 \%)$. In Figure 3, (a) and (c) show that two series of data, obtained at Binhdai and Bentrai, have unremarkable fluctuations and traces smaller than those of the measured water level; these variations are similar to the amplitude of variation of the simulated results. Good agreement was also noted between the computed and observed velocity at the three points shown in Fig. 2 as 1, 2, and 3. In Figure 3, (b) and (d) delineate the same order between the computed velocity results and observed data in the Dai and Cochien estuaries, shown as point 1 and 3 in Fig. 2.

(2) Wave

The computed wave height results were also calibrated with measured data obtained from the two observation stations, shown as points 4 and 5 in Fig. 2. Figure 4 shows a discrepancy between the modeled result and measured data, which is attributed to sparse wave data. The boundary wave conditions were determined on the basis of monthly averaged wave data. However, the fluctuations of measured data and computed results are reasonably similar.

(3) Sediment

Figure 5 shows the computed sediment result and observed data for monitoring points 6 and 8 , shown as points $6,7,8$, and 9 in Fig. 2. The variations of the computed and observed series were similar and concurrent. The maximum measured data value was slightly larger than the corresponding model prediction, whereas the minimum observed data and computed result had nearly the same value (Fig. 5

Table 1. Bed parameters in the Mekong River estuary model based on observed data

\begin{tabular}{|c|c|c|c|c|c|c|}
\hline $\begin{array}{l}\text { Layer } \\
\text { number }\end{array}$ & Mud Type & $\begin{array}{c}\text { Density of } \\
\text { bottom Sediment } \\
(\mathrm{g} / \mathrm{L})\end{array}$ & $\begin{array}{c}\text { Critical shear } \\
\text { stress for Erosion } \\
\tau \mathrm{cre} \\
\left(\mathrm{N} / \mathrm{m}^{2}\right)\end{array}$ & $\begin{array}{c}\text { Erosion } \\
\text { coefficient } \\
\text { E } \\
\left(\mathrm{kg} / \mathrm{m}^{2} / \mathrm{s}\right)\end{array}$ & $\begin{array}{c}\text { Coefficient } \\
\qquad \begin{array}{c}\alpha \\
\left(\mathrm{m} / \mathrm{N}^{0.5}\right)\end{array}\end{array}$ & Initial Thickness \\
\hline 1 & Mobile fluid mud & 120 & $0.17-0.20$ & 0.000005 & 5 & $0.05-0.3$ \\
\hline 2 & Partly consolidated mud & 300 & $0.35-0.40$ & 0.000001 & 4 & $1-2$ \\
\hline 3 & Partly consolidated mud & 450 & $0.55-0.60$ & 0.000001 & 4 & $4-6$ \\
\hline 4 & Hard mud & 600 & 1.50 & 0.0001 & & 10 \\
\hline
\end{tabular}

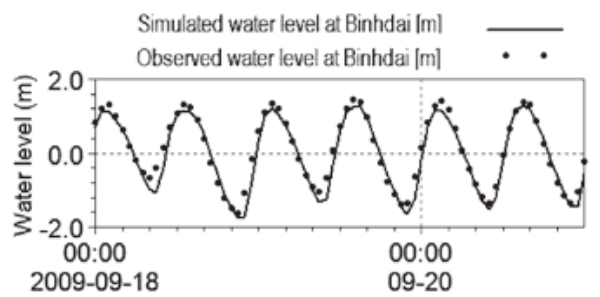

(a)

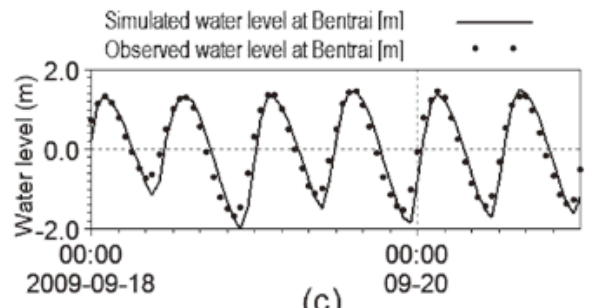

(c)

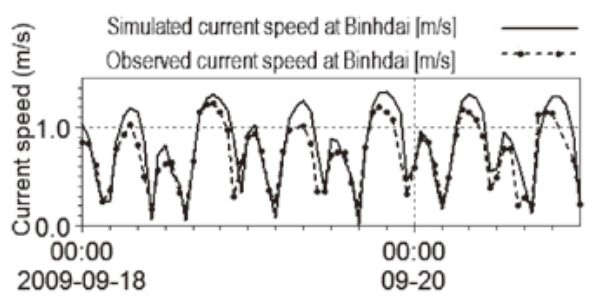

(b)

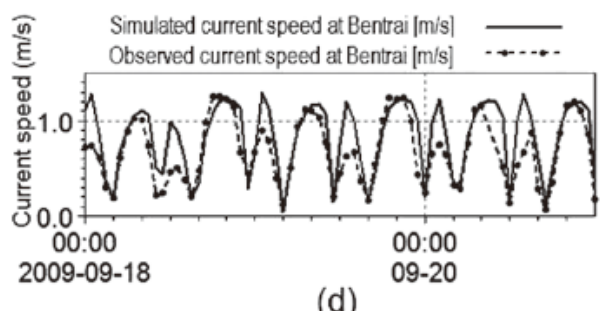

(d)

Fig. 3. Observed data (OBS) and computed water level and velocity 
(a), point 6; Fig. 5 (b), point 8). Given the uncertainty in the measurement, the model was considered well calibrated.

\section{Model application}

In the period from 2000 to 2005 , two strong flood seasons (in 2000 and 2003) and two of the driest seasons (in

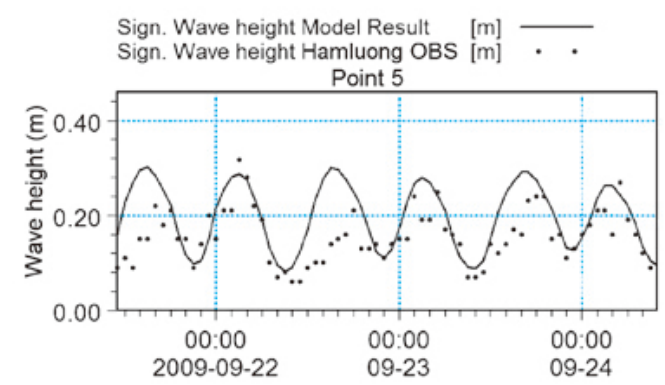

Fig. 4. Computed wave height and observed data (OBS)
2001 and 2002) were selected for simulation to assess the impact of seasonal river discharge. Another detailed simulation was later conducted to investigate the effects of sea current and waves on morphological evolution. The detailed model had the same setting as that in the dry season in 2001, but excluded waves. The results were then compared with actual values.

\section{Flow}

Figure 6 shows the flow field in the Tien River estuary area during the flood season in 2000 (Fig. 6 (a)) and the dry season in 2001 (Fig. 6 (b)). In the Tien River estuary area, the river current dominates in the flood season and the sea current dominates in the dry season. The maximum value of velocity appears in the Tieu River, and river currents in the flood season are stronger than those in the dry season, thereby causing the Tien riverbed to erode more rapidly in the flood season than in the dry season. Riverbed erosion is clearly manifested in the Hamluong, Tieu, and Dai rivers. The current velocity is low in the Cochien and Cunghau

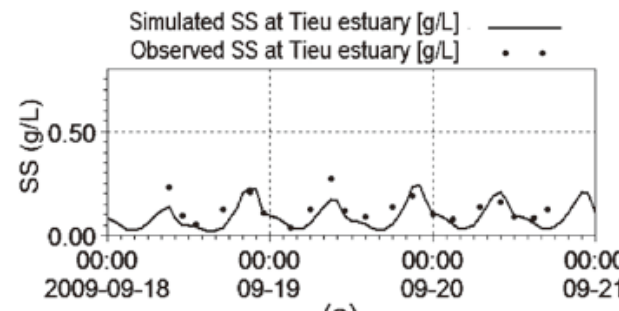

(a)

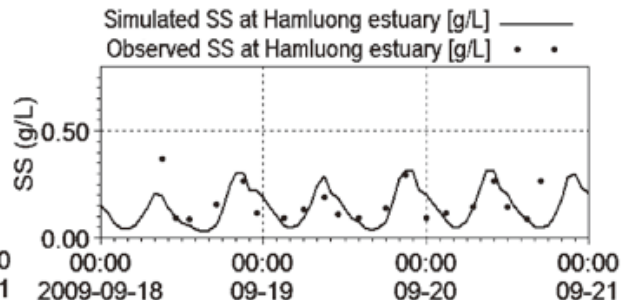

(b)

Fig. 5. Computed suspended sediment concentration (SSC) and observed data (OBS)

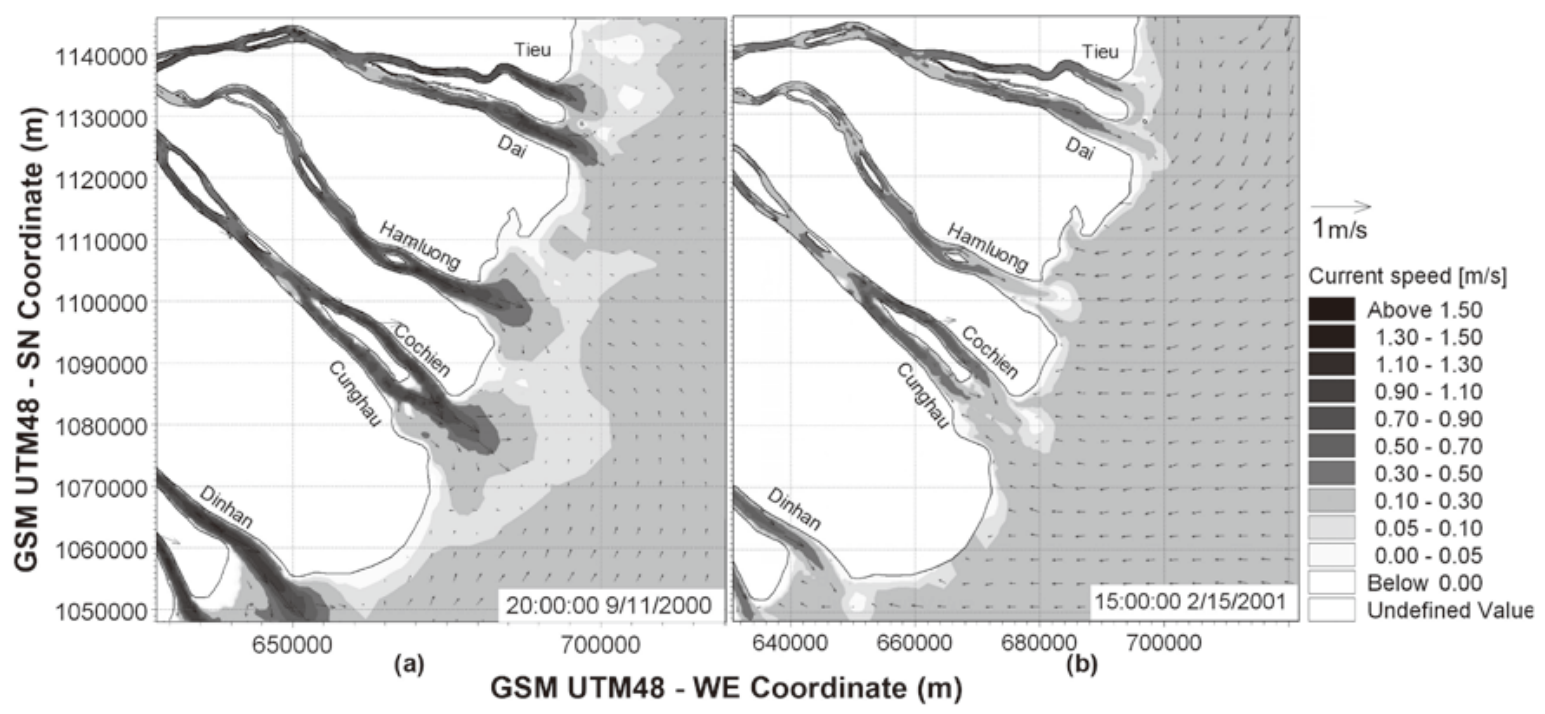

Fig. 6. Computed current speed: (a) 2000 flood season; (b) 2001 dry season 
rivers; therefore, deposition occurs more readily near the banks of these rivers than that in other branches of the Tien River.

\section{Mud transport and morphological evolutions}

During the high flow season, sediment is carried from the mouths of rivers before being distributed in the distal zone among all estuaries of the Tien and Hau rivers (Fig. 7). Table 2 shows that the sediment concentration peaked in the flood season of 2000, which was also the wettest in the six-year study period. The smallest value of mean sediment concentration was noted during the dry season in 2001, which was the driest season. The results from the flood seasons in 2000 and 2003 indicate that the influence of river current on sediment transport is significant. Although the two flood seasons have the same upstream sediment boundary, the mean values of sediment in 2003 were approximately two-thirds of those in 2000. The low river discharge in the flood season of 2003 resulted in a river current with insufficient strength to transport the sediment to the sea.

The numerical model predicted (Fig. 8 and Fig. 10) that the Tien riverbed was strongly eroded, reaching $-0.3 \mathrm{~m}$ in the flood season. In both seasons, the riverbanks were both aggraded and degraded. Sediment was deposited in

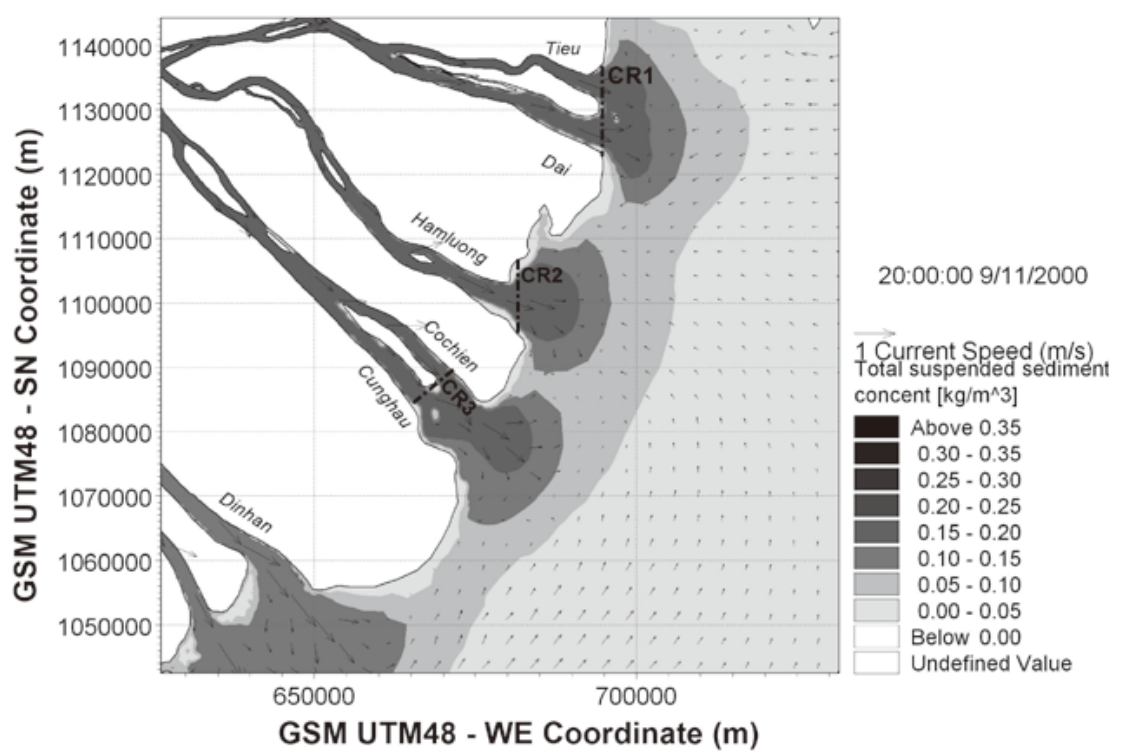

Fig. 7. Computed sediment concentration

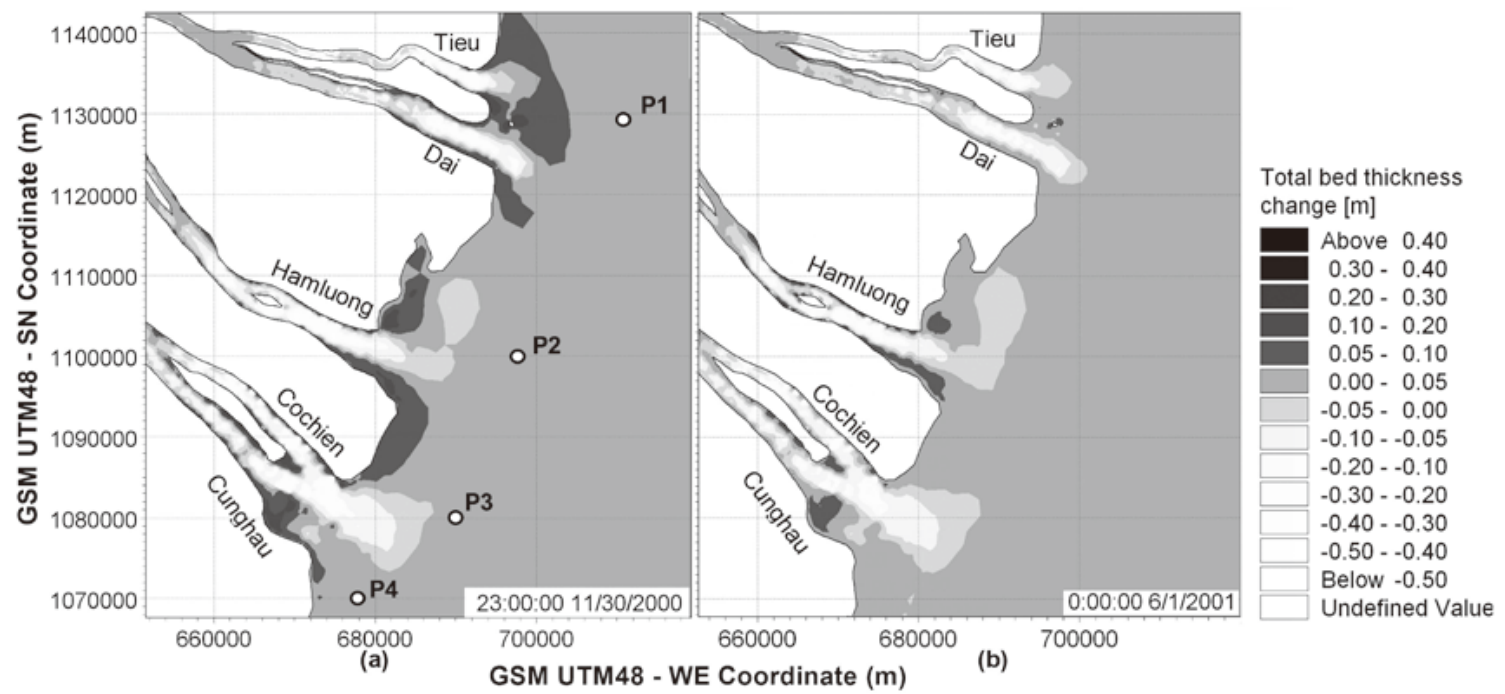

Fig. 8. Computed bed thickness changes: (a) 2000 flood season; (b) 2001 dry season 
the river mouth area during the flood season; however, a portion of this sediment may be moved during the next dry season. The characteristics of the Cochien and Cunghau estuaries indicate that accretions are significant in the tail of islets between the two estuaries year-round. This process in the Dai and Tieu estuaries is similar during the flood season, although erosion occurs during the dry season. In contrast, accretions appear on both sides of the riverbed, and erosion is negligible in the middle of the Hamluong estuary. The morphological evolution results of this study are in good agreement with those reported in previous studies (Tran 1981, Vu 2007, Vu 2010, SIWRR 2003).

\section{Waves}

Figure 9 provides the predicted surface elevation, wave height, and bed thickness change at point P4 in Fig. 8 for January 2001. This month includes one of the strongest wave fields, with a mean offshore wave height of $2.6 \mathrm{~m}$. In Fig. 9, the surface elevation time series indicates that the spring tide occurred twice in January; the first (from January 9 to January 15) was larger than the second. Conversely, the significant wave height in the neap tide was higher than that in the spring tide. The bed thickness changes with and without waves show that erosion occurred at that site. The bed level was nearly unchanged from January 1 to January 9, but quickly decreased between January 9 and January 15 . From that time until the second spring tide on January 24, the bed level was stable before again decreasing. Nevertheless, the second decrease in bed level was smaller than the first, as was noted for the spring tide. More importantly, the bed thickness change value of the simulation without waves was half that when including waves. Thus, sea current is the main factor in shoreline erosion, particularly during the spring tide; wave action is a secondary factor.

\section{Analysis of Model Results}

\section{Influences of key factors on sediment transport}

(1) River current

In the flood season, river flow dominates in the distal zone; when the river current interferes with sea currents, a quiescent water area forms far from the river mouth
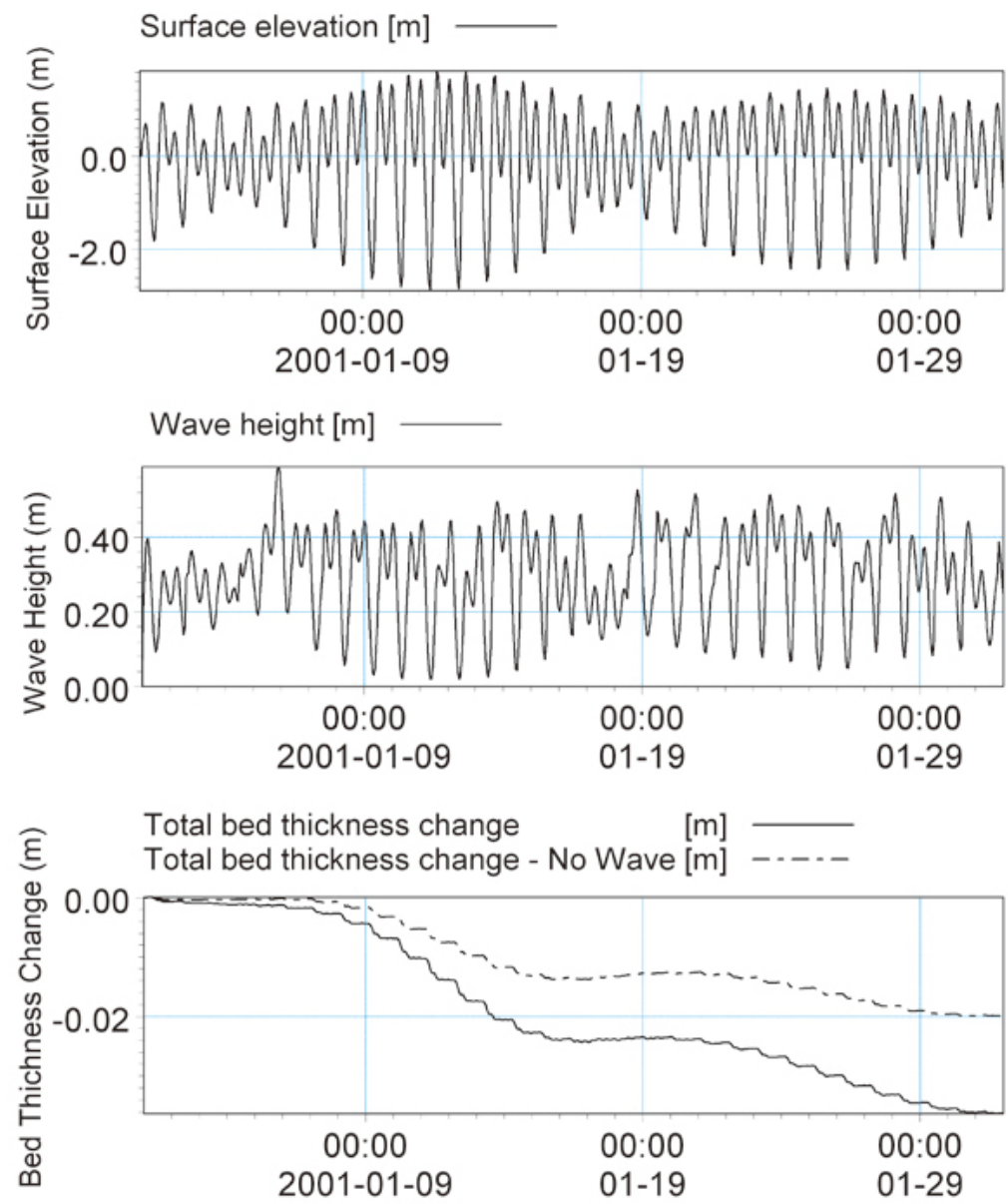

Fig. 9. Computed surface elevation, wave height, and bed thickness changes at point P4 
(Fig. 6), where sediment easily settles out of suspension (Figs. 7, 8). In the dry season, the river current is relatively weak, while the cold sea current in the dry season is strong and reduces the river current in the distal zone, causing shrinkage of the quiescent water area near the river mouth. Hence, the movement of sediment from upstream to the sea is impeded. In the river, the flows from upstream drive riverbed erosion and deposition along riverbanks. The flow carries sediment out of the Tien River mouth area, where the sediment is deposited in shallow coastal waters. In the distal zone, the river current combines with tidal current to govern the development of a narrow passage and sand bars at the river mouth (see Fig. 10).

(2) Sea current and tide

In general, the influence of tidal and sea currents is appreciable in tidal estuaries such as the Tien River estuary. The combination of river current, tidal current, wave, and sea current helps to drive the nearshore current. During the wet season, the nearshore current flows northward; whereas in the dry season, it flows southward in the same direction as the cold strong sea currents (Fig. 6). Therefore, the velocity of nearshore current in the dry season is higher than that in the wet season. In the dry season, the spring tidal current flows into the river under the influence of the strong cold sea current, causing the river mouth to become deficient in sediment supplied from upstream and resulting in weakened sedimentation processes near the mouth of the river. In the flood season, the nearshore current is weak and the strong river current dominant, resulting in riverbed scouring and substantial erosion at the river mouth. However, low current velocities occur near riversides and islets between the estuaries; thus, suspended sediment is deposited in these areas. Such deposition and erosion processes cause the river cross section to become narrower and deeper.

In the distal zone, the nearshore current considerably influences the patterns of sediment transport. After moving out of the river mouth, the sediment is transported southward or northward along the coastline by the nearshore current. Nevertheless, the strong cold current flows southward and leads significant sediment to drift down to Cape Ca Mau.

\section{(3) Waves}

In addition to sea current, waves also act to intensify the shoreline. During the dry season, the reciprocal action between currents induced by monsoon waves and the nearshore currents causes structural instability along the shoreline. SIWRR (2006) pointed that the subsurface layer is weak; therefore, the shoreline is rapidly eroded when strong waves occur. The broken soil and sediment of the shoreline are pulled into the sea via this nearshore current
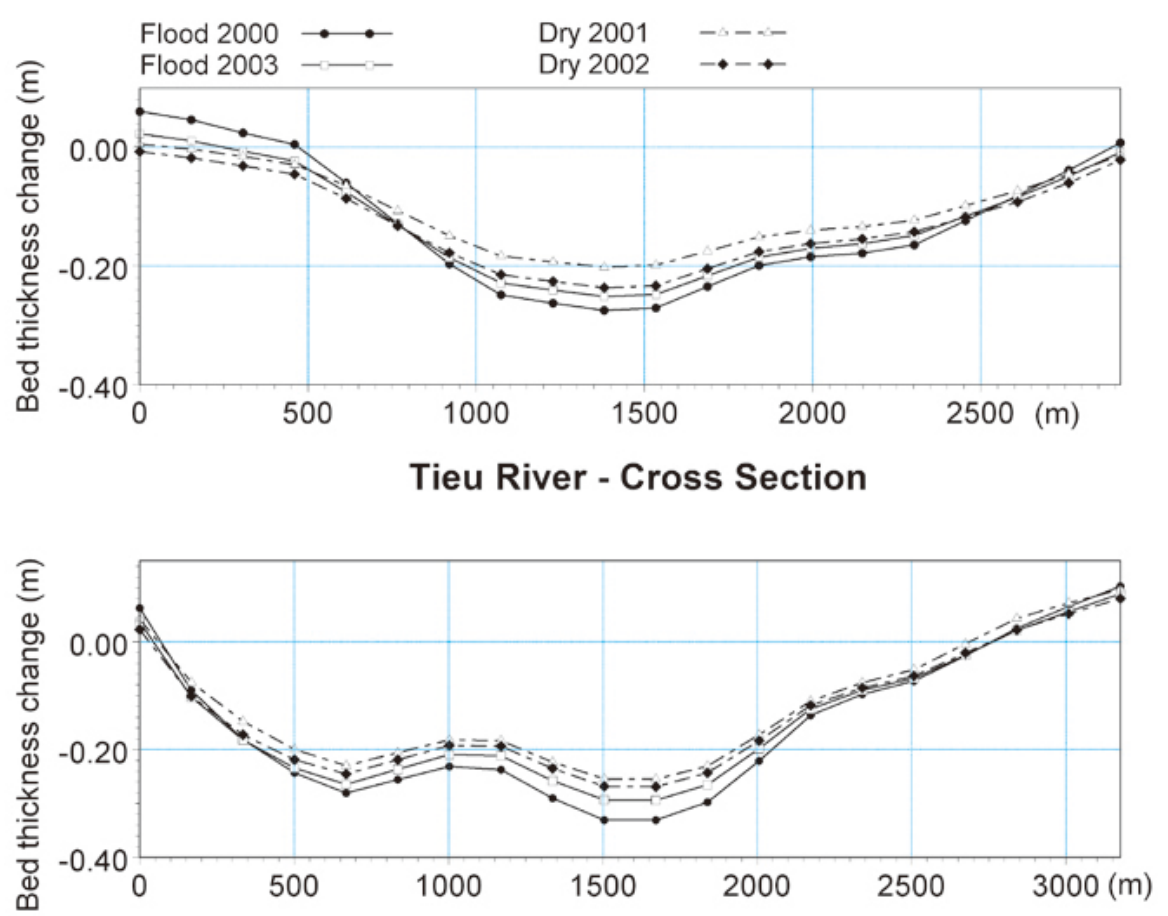

Hamluong River - Cross Section

Fig. 10. Computed bed thickness change of the Tieu and Hamluong rivers 
and transported by sea currents, eventually being deposited in the southern Mekong Delta. This movement obviously leads to shoreline erosion, and also results in suspended sediment moving southward after flowing out of the river (Fig. 11). However, erosion is rapid in the Tieu and Dai estuaries, whereas some deposition still occurs at the mouths of the Hamluong, Cochien, and Cunghau rivers in the dry season. The main reason for this deposition is the estuarial setting. These estuaries are indented and sheltered from sea currents; hence, the sediment is not affected by sea current to the same degree as that in the Tieu and Dai estuaries (illustrated in Fig. 8).

\section{Mud transport and morphological processes}

The movement of suspended sediment is the same as current field and the formula of sediment transport is given seasonally. In the flood season, due to the high river discharge and high sediment flux, suspended sediment is transported to the mouth of the Tien River and deposited offshore where it encounters saltwater. Nevertheless, the sediment flux is several times smaller in the dry season than in the flood season (Table 2), and the main reason for insufficient suspended sediment in the estuarial area (Table 3).

In the Tieu and Dai estuaries, accretion and erosion occur alternately in the nearshore zone; thus, the coastline change is negligible (see Fig. 11). In these areas, the riverbed is eroded, whereas the riverbanks are mostly consolidated. However, the strong cold sea current in the dry season results in sporadic river shore erosion where the bank foundations are weak. Although sandbars are created and fortified during the flood season, they erode and migrate slightly onto the coast during the dry season.

The morphological processes of the Hamluong River are similar to those of the Tieu and Dai rivers. Nevertheless, considerable deposition occurs at the river mouth. Since the south riverbank bulges more than the north riverbank, the sediment easily settles in the low-velocity region in the northern river mouth. Therefore, the north shoreline extends into the sea, whereas the south shoreline erodes somewhat at the headland.

The sedimentation processes in the Cochien and Cunghau estuaries differ slightly from those in three estuaries discussed above. Remarkable accretion occurs in the river and creates new islets. At the river mouth, sediment deposits are found along both sides and at the end of the existing islet between the two estuaries. Hence, this islet extends into the sea. However, in the dry season, strong cold sea currents and insufficient sediment cause fretting along the south shoreline of the Cung Hau estuary.

Compared with previous studies, the morphological evolution results of this study have good agreement. $\mathrm{Vu}$ (2007) showed that the processes of deposition and erosion along the riversides and shorelines of the Tieu and Dai estuaries were slow. In the distal area, an unstable sandbar was created and it moved to connect with the existing sandbar or islet. During these processes, the shorelines of the Hamluong estuary changed remarkably and the riversides were slightly fretted. The north shoreline of the Hamluong estuary greatly expanded into the sea. The same processes of accretion and erosion occurred in the Cochien and Cunghau estuaries. There were new islets in the mouth area of the Cunghau and Cochien rivers. The alluvial land between those two rivers was extended by deposition. Tran (2008) showed the same results. From 1989 to 2004, erosion took place in the Hamluong River, particularly at the Tieu and Dai estuaries. At the same time, the mouth area of the Cochien and Cunghau rivers was largely consolidated. Besides the changing shorelines of the Tien River estuary as noted in the studies above, the survey projects of SIWRR (2006) also elaborated that the riverbeds of the Tieu and Dai rivers were significantly eroded (0.3-0.4 meter per year) near the river mouth. Similar degradation occurred in the riverbed of the Hamluong River, and this erosion was even worse than in the Tieu and Dai rivers, with the values of bed level change being able to reach $0.5 \mathrm{~m}$ per year.

\section{Conclusions}

This study has investigated the sediment problems in the Tien River estuary, Mekong River, Vietnam. Two largescale numerical models have been established to identify the morphological evolution of this estuary. The simulated results in this study suggest that the effects of river currents, tides, sediment concentration, waves, and salinity are considerable on estuary morphodynamics. The key points of this study are summarized below.

- River current is a key factor for the morphological evolution of the Tien River estuary. The river flow rates determine the riverbed erosion and riverbank deposition processes. In the distal zone, river current combined with tidal current governs the development of narrow passages and islets.

- Sea current plays a major role in shoreline alteration, whereas tidal current is a contributing factor in bed erosion at the river mouth.

- Wave action is a secondary factor that intensifies shoreline erosion and is primarily influenced by sea current.

- Strong erosional and depositional processes have occurred in the Tien River estuary. The Tien River cross section has become narrower and deeper due to riverbed erosion and the accretion of riverbanks. The accretions of riverbanks and shorelines have led to further extension of the Tien River into the East Sea.

- Sediment deposition is greatest during the flood season, creating sandbars and strengthening existing islets. However, part of this sediment is entrained in the flow 

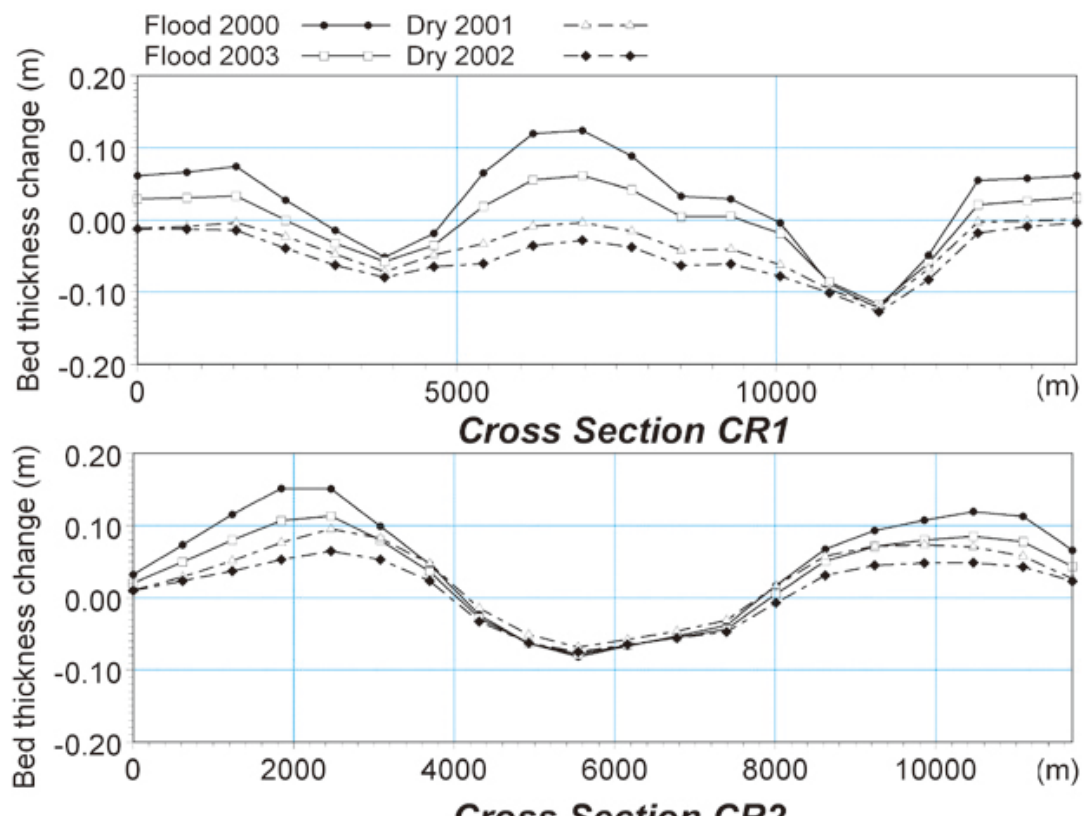

Cross Section CR2

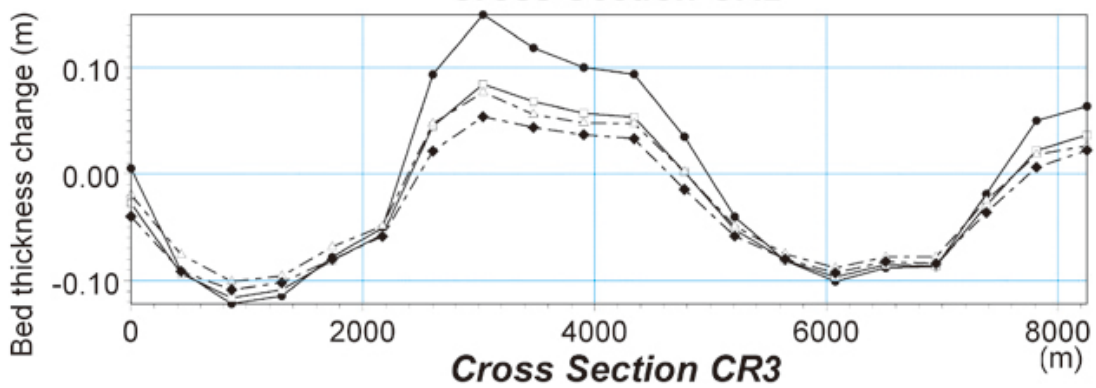

Fig. 11. Computed bed thickness change of the cross section at the river mouth of the Tieu-Dai (CR1), Hamluong (CR2), and Cochien-Cunghau estuaries (CR3)

Table 2. Computed mean suspended sediment at the mouth of the Tien River

\begin{tabular}{lccc}
\hline \hline Season - Year & \multicolumn{3}{c}{ Mean suspended sediment concentration (mg/1) } \\
\cline { 2 - 4 } & Tieu-Dai (CR1) & Hamluong (CR2) & Cochien-Cunghau (CR3) \\
\hline Dry Season 2001 & 49.52 & 62.22 & 64.21 \\
Dry season 2002 & 51.39 & 66.77 & 67.54 \\
Flood season 2000 & 139.09 & 149.20 & 152.37 \\
Flood season 2003 & 88.66 & 100.61 & 109.77 \\
\hline
\end{tabular}

Table 3. Suspended sediment concentration and bed thickness change at 3 points - out of river mouths

\begin{tabular}{|c|c|c|c|c|c|c|}
\hline \multirow[t]{2}{*}{ Season - Year } & \multicolumn{3}{|c|}{$\begin{array}{l}\text { Suspended sediment concentration } \\
\qquad(\mathrm{mg} / \mathrm{l})\end{array}$} & \multicolumn{3}{|c|}{$\begin{array}{l}\text { Total bed thickness change } \\
\qquad(\mathrm{cm})\end{array}$} \\
\hline & $\mathrm{P} 1$ & $\mathrm{P} 2$ & P3 & $\mathrm{P} 1$ & $\mathrm{P} 2$ & P3 \\
\hline Flood, 2000 & 66.58 & 76.26 & 67.58 & 2.22 & 2.07 & 1.76 \\
\hline Dry, 2001 & 22.61 & 32.73 & 31.30 & -2.13 & -2.14 & -2.46 \\
\hline
\end{tabular}


and transported southward during the following dry season.

\section{Acknowledgments}

This research was partially supported by the FY 20122014 JSPS Core-to-Core Program (B. Asia-Africa Science Platforms) Collaborative Project for Soil and Water Conservation in Southeast Asian Watersheds and FY2011-2015 JSPS Grant-in-Aid for Scientific Research (B) (Project number 23380144).

\section{References}

Davis, R. A. \& Hayes, M.O. (1984) What is a wave-dominated coast? Marine Geology, 60, 313-329.

DHI (2007a) Mike 21 Flow model FM Hydrodynamic module scientific documentation.

DHI (2007b) Mike 21 Spectral Wave Module Scientific documentation.

DHI (2007c) Mike 21 Flow model Mud transport Module Scientific Background.

Dou, G. (2000) Incipient motion of sediment under currents. China Ocean Eng., 14(4), 391-406.

Dyer, K. (1989) Sediment processes in estuaries: future research requirements. Journal of Geophysical Research, 94, 1432714339.

Gagliano, S. M. \& McIntire, W. G. (1968) Reports on the Mekong River Delta: UNC-CSI. Louisiana State University Technical Report, 57, 144.

Gottschalk, L. C. (1977) Predicting erosion and sediment yields. Intern. Union of Geodesy and Geophysics, Association of Scientific Hydrology. XI General Assembly, Toronto, Canada, Tome I, Vol. 1, 146-153.

Hayes, M. O. (1979) Barrier island morphology as a function of tidal and wave regime. In: Leatherman, S.P. (Ed.), Barrier Islands. Academic Press, New York, 1-27.

Hoang, V. H. \& Nguyen, H. N. (2006) Results on study about wave field of Dongnai- Saigon estuaries and suggestion of sea bank and river mouth protection methods. VietnamJapan Estuary Workshop in collaboration between Tohoku University and Water Resources University, August 22-24, 2006, 140-150.

Holeman, J. N. (1968) The sediment yield of major rivers of the world. Water Resour. Res., 4, 737-747.

Hong, D. L., Gao, Y. J., Xie, R., Ji, C. H. \& Shen, X. (2007) Experimental study on silt incipient motion under wave action. China Ocean Engineering, 21(4), 677-688.

Houwing, E. J. \& Van Rijn, L. C. (1998) In Situ Erosion Flume (ISEF) Determination of bed shear stress and erosion of a kaolinite bed. Journal of Sea Research, 39, 243-253.

Houwing, E. J. (2000) Sediment dynamics in the pioneer zone in the land reclamation area of the Waddenzee, Groningen, The
Netherlands. Doctoral thesis, University of Utrecht, Utrecht, The Netherlands.

Julien, P. Y. (1998) Erosion and sedimentation. Cambridge University Press, Cambridge, New York.

Krone, R.B. (1962) Flume Studies of the Transport of Sediment in Estuarial Shoaling Processes. Technical Report, Hydraulic Engineering Laboratory, University of California, Berkeley California.

Letrung, T., Li, Q., Li, Y., Vukien, T., and Nguyenthai, Q. (2013) "Morphology Evolution of Cuadai Estuary, Mekong River, Southern Vietnam." Journal of Hydrologic Engineering, 18(9), 1122-1132.

Lumborg, U. \& Windelin, A. (2003) Hydrography and cohesive sediment modeling: application to the Rømø Dyb tidal area. Journal of Marine Systems, 38, 287-303.

Mehta, A. J., Hayter, E. J., Parker, W. R., Krone, R. B. \& Teeter, A. M. (1989) Cohesive sediment transport: Part I. Process description. Journal of Hydraulic Engineering, 115, 1076-1093.

Mekong River Commission (MRC) (2005) Overview of the Hydrology of the Mekong Basin. November 2005.

Mikhailov, V. N., \& Arakelyants, A. D., (2010) Specific Features of Hydrological and Morphological Processes in the Mouth Area of the Mekong River. Water Resources, 37(3), 253-267

Ngoc, T. A., Letrung, T., Hiramatsu, K., \& Nguyen, T. Q. (2013) The Effect of Simulated Sea Level on the Sedimentation of the Tien River Estuaries, Lower Mekong River, Southern Vietnam. Japan Agriculture Research Quarterly, 47(4), 405-415.

Nguyen, Q. K. (2009) Project investigation sensible exploit of freshwater, compatible with development scenario in Upper Mekong River and sea level rise. Second base of Water Resources University Vietnam. Unpublished.

Nguyen, V. L., Ta, T. K. O. \& Tateishi, M. (2000) Late Holocene depositional environments and coastal evolution of the Mekong River Delta, Southern Vietnam. Journal of Asian Earth Science, 18, 427-439.

Parchure, T. M. \& Mehta, A. J. (1985) Erosion of soft cohesive sediment deposits. Hyd. Eng., ASCE, 111 (10), 1308-1326.

Rubey, W. W. (1933) Settling velocities of gravel, sand, and silt particles.' Am. J. Sci., 25, 325-338.

Schubel, J. R. (1968) Suspended sediments of the northern Chesapeake Bay. Chesapeake Bay. Institute of the Johns Hopkins University, Tech Report, 35, 264.

Shi, Z. \& Zhou, H. J. (2004) Controls on effective settling velocities of mud flocs in the Changjiang Estuary, China. Hydrol. Sci., 18, 2877-2892.

SIWRR, Vietnam (2003) Project Survey Tien River's estuaries and Hau River's estuaries 2002-2006 (unpublished), part 1.

SIWRR, Vietnam (2007) Project Survey Tien River's estuaries and Hau River's estuaries 2002-2006 (unpublished), part 2.

Ta, T. K. O., Nguyen, V. L., Tateishi, M., Kobayashi, I. \& Saito, Y. (2001) Sedimentary facies, diatom and foraminifer assemblages in a Late Pleistocene- Holocene incised-valley 
sequence from the Mekong River Delta, Bén Tre Province, Southern Vietnam: the BT2 core". Journal of Asian Earth Science, 20, 83-94.

Tamura, T., Horaguchi, K., Saito, Y., Sieng, S., Nguyen, V. L., Tateishi, M., Ta, T. K. O., Nanayama, F. \& Watanabe, K. (2010) Monsoon-influenced variations in morphology and sediment of a mesotidal beach on the Mekong River Delta coast. Geomorphology, 116, 11-23.

Teeter, A. M. (1986) Vertical transport in fine-grained suspension and newly deposited sediment. In: Mehta, A. J. (Ed.), Estuarine Cohesive Sediment Dynamics. Springer-Verlag, Berlin, 170-191.

Teisson, C. (1991) Cohesive suspended sediment transport: feasibility and limitations of numerical modeling. J. Hydraul. Res., 29 (6), 755-769.

Thorn, M. F. C. (1981) Physical processes of siltation in tidal channels. Proceedings of Hydraulic Modeling Maritime Engineering Problems, ICE, London, 47-55.

Tran, T. V. \& Tran, T. T.(2008) Shoreline change detection to serve sustainable management of coastal zone in Cuu Long estuary. Institute for Environment and Resources, Vietnam National University Ho Chi Minh City.

Vu, K. T. (2007) Project: Research origination, development and propose hydraulic solutions, exploitation of alluvial ground in coastal zone of Southern Vietnam - Part 1. Second base of Water Resources University Vietnam (unpublished).

Vu, K. T. (2010) Project: Research origination, development and propose hydraulic solutions, exploitation of alluvial ground in coastal zone Southern Vietnam - Part 2. Second base of Water Resources University Vietnam (unpublished).

Van Rijn, L. C. (1989) Transport of cohesive materials. Delft Hydraulics H 461, 12.1-12.27.

Van Rijn, L. C. (2007) Unified view of sediment transport by currents and waves. Part 1, 2, 3, 4. J. Hydraul. Eng., 649667.

Wolanski, E., Nguyen, N. H., Le, T. D., Nguyen, H. N. \& Nguyen, N. T. (1996) Fine sediment dynamics in the Mekong River Estuary, Vietnam. Estuarine, Coastal and Shelf Science, 43, 565-582. 